\title{
Analysis of Traditional Clothing on Buru Island
}

\author{
Tim Kerja PSP2M Uniqbu
}

\begin{abstract}
Customary clothing becomes an important part in every ritual and customary activities for the community in the island of Buru, the function of traditional clothing in addition to body armor is also a symbol of identity attached to the outfit. This research is a qualitative study aimed at describing indigenous fashion for the community. The research location focuses on three villages namely Kayeli village, Kubalahin Village and Wasi Village with consideration of the traditional clothing use which is more often found in comparison of other villages in Buru Island. The number of informant interviewed by 25 people, consisting of customary figures, community leaders, leaders of indigenous institutions and village apparatus as well as local people residing at the research site. Analytical techniques used to follow the concept of Miles and Huberman where activities in the analysis of qualitative data are conducted interactively and continuously. The results showed that customary clothing in all three locations had several similarities in the use as well as differences in the placement of custom fashions. The villagers of Kayeli and Wasi used traditional clothes for the activities of receiving indigenous guests and traditional activities that took place in the village, while the community was kubalahin using traditional clothes while the traditional ritual was carried out. For people of the village Kayeli customary clothing has a value of sacral that must be obeyed by everyone who uses it, as well as in the village of Wasi and Kubalahin, they assume that identity in the customary clothing should be maintained with not arbitrary use Or placing custom clothes in everyday life.
\end{abstract}

Keywords: Fashion, Custom, Local Communities, Namlea, Buru, Semiotic

\section{INTRODUCTION}

Buru Island is one of the Great islands in Maluku Province, the population in 2018 was 132,100 people. Buru Island with a wealth of traditions has long been one of the cultural destinations in Maluku province that has not been fully explored such as the existence of Lake Rana, Boki Feten dance, VOC Fortress in Kayeli state and the heritage of the community structure divided Become autoclaved and Alokton[1]. From a number of cultural destinations in Buru Island, one of the traditional culture of society and has its own special privileges is customary clothing, where the customary clothing is divided into two namely for men with the name of Pakean adat and The woman is commonly called Kabaya[2].

The existence of customary clothing for the community in the island of Buru can not be removed from the ceremonial or ritual activities where the customary clothing becomes an identity that has its own meaning for everyone who uses it. The word fashion literally means a complete outfit (a beautiful one) and glorious, unnecessarily fancy fashion. When viewed from the aspect, such as aesthetic aspect (beauty), and also the direct aesthetic aspect or indirect function to beautify and add a noble impression on the clothes worn by a person certainly in it also related values and symbolically[3].

Meanwhile, customary clothing is a clothing that is hereditary used by the community in his day with the characteristics that indicate the local culture created the traditional fashion. Traditional clothing develops in harmony with the development of culture. The use of custom clothing adjusts to the government system in which the society lives[4]. Alip Sugianto in his study of etnolinguistics on the customary clothing Warok Ponorogo, showed that there is a difference in the Warok Ponorogo clothes that are used by old Warok, Warok Mudha and Warokan or students Warok. The three garments have their meanings and meanings that are not the same between the three. The difference is due to certain factors such as age and the role in the main community in the exercise[5]. In addition, Herlinda Marlina in her research to understand the motive in the customary clothing suggests that the customary pattern for the Dayak tribe has a good reciprocal relationship between humans and the surrounding natural that will benefit the generation of People now and in the future. The Motif of Dayak Kenyah ethnic clothing contains idealistic values on the way of life adopted by the Dayak Kenyah people[6].

For the community in Buru Island, customary clothing for women is a cultural sign that is very valuable and is owned by most indigenous tribes in the island of Buru and has its own meaning and significance for the tribe[7]. In general, people think that customary clothing is part of the arts, and the art itself is interpreted as a result of the expression of human soul for beauty. Actually, not all works of art can be stated, because there are artworks that better put the message of the culture of the community concerned.

The research on the semiotics analysis of Dayak Bahau customary clothing conducted by Melkias Jalung in 2015 showed that clothing as a means of cultural communication of Dayak Bahau tribe until now still experiencing development and little A slight shift in cultural significance. Where now the user of clothing is no longer a person from the Dayak Bahau tribe only, but outside of the tribe[8].

The study of indigenous fashion for women in Buru Island aims to integrate problems in social life in the image of society to achieve a common need, such as glory, unity, and mutual respect for each Other. Semiotics study in the use of women customary in Buru Island will certainly explain more details about the meaning and meaning itself. The author attempts to know deeper by studying it through a semiotic theory, where the author examines the "Mark" as his semiotician study. Semiotika is derived from the Greek word 'semeion' or sign, often interpreted as a sign science. Later, Lambert, a German philanthroreist popularized the term Semiotika[9], in the 18th century as a word equivalent of logic. In the development of semiotics not only serve as the science of signs, but also examine how the signs function, also how to do with other signs, besides also the process of delivery and acceptance by its users[10]. This research was conducted based on the preference of the semiotics approach of traditional clothing in Buru Island with the aim to see the community's mindset in Buru Island through 
signs of symbolism of various colors and shapes, so that The sign is a form of value construction built by indigenous peoples in the island of Buru.

\section{LITERATURE REVIEW}

\subsection{Semiotics}

The process of marking processing on Peirce follows the relationship between the three points of the representative (R) object (O) - Interpretant (I). $\mathrm{R}$ is a part of the sign that can be physically or mentally enrable, referring to something represented by it (O). Then I was part of the process that interpreted the relationship between R and O[11]. Therefore for Pierce, the sign is not only representative, but also interpretive [8]. The Peirce theory of marking shows the use of signs as a cognitive process rather than a structure[12]. Reviewed from his relationship, Pierce distinguishes the top three marks, namely; (1) Icons: A sign that occurs based on potential equations with something it signiuses (such as maps and geographical areas, photographs with objects, paintings with ideas). (2) Index: A sign whose nature depends on the existence of a dentate, or has a causal link to what it represents (such as: Traffic signs). (3) Symbol: A sign determined by a general prevailing rule, a joint agreement or convention (such as: body movements or nod of head as a sign of consent).

In addition to the two semiotics of the above (Peirce and De Saussure), the semiology of the communications developed by Hjelmslev, a Danish national structuralist[13][14]. The scope of the study is a sign with a certain intent; such as signals (signal), and signs with no intention as symptom. A well-known character is Roland Barthes, known as the conotative semiotic figure Barthes presents a semiotic theory called the signification of two phases [9]. Barthes explains that this concept begins with the relationship between signifier (expression) and signified (content) in a sign against an external reality that is a signification of the first phase.

It is called Barthes as the dennotation of the most obvious meaning of the mark[15]. The signification of the second stage called the Connotation by Barthes, describes the interactions that occur when the sign meets the feelings or emotions of the reader and the values of its culture. In other words the dennotation is what the mark is depicted on an object, while the meaning of the connotation is how to describe it. The denotative meaning includes the things designated by the words, or the explicit relationship between the mark by reference or reality in marking the denotative stage. For example there are human drawings, animals, trees, houses with red, yellow, blue, and white[16][17]. At the denotative stage only the data information is delivered. While the meaning of the conotatives covers the aspects of color related to the feelings and emotions and cultural values and the viewpoint of a community, example: the image of a smiling face can be interpreted as happiness or expression of humiliation, To understand the meaning of conotative, the other elements must be understood anyway.

In the Liguistic sciences the understanding between the dentations and the connotations is distinguished in its linguistic charge[18]. In the connotations, the aspect of the expression is much greater than the content of understanding found in the dennotation. Thus for the language of the scholarly or information, it is more appropriate to use a denotative understanding. As for the disclosure of expressions of expression, such as novels, poems, essays, or poetry, its use tends to be convolative. Similarly, in visual language for technical drawings, information or aspects related to production, information or aspects related to production, it tends to be used in denotative visual signs, so it is not Meaning refrfitting occurs. As for things that are charged expressions, such as form, image, motif, ornament or things that come into contact with the aspect of humanitis, tends to apply signs of conotative[19]

\subsection{Traditional Dress}

The process of marking processing on Peirce follows the relationship between the three points of the representative (R) object (O) - Interpretant (I). $\mathrm{R}$ is a part of the sign that can be physically or mentally enrable, referring to something represented by it (O). Then I was part of the process that interpreted the relationship between $\mathrm{R}$ and $\mathrm{O}[20]$. Therefore for Pierce, the sign is not only representative, but also interpretive [8]. The Peirce theory of marking shows the use of signs as a cognitive process rather than a structure[21]. Reviewed from his relationship, Pierce distinguishes the top three marks, namely; (1) Icons: A sign that occurs based on potential equations with something it signiuses (such as maps and geographical areas, photographs with objects, paintings with ideas). (2) Index: A sign whose nature depends on the existence of a dentate or has a causal link to what it represents (such as: Traffic signs). (3) Symbol: A sign determined by a general prevailing rule, a joint agreement or convention (such as: body movements or nod of head as a sign of consent).

In addition to the two semiotics of the above (Peirce and De Saussure), the semiology of the communications developed by Hjelmslev, a Danish national structuralist[8]. The scope of the study is a sign with a certain intent; such as signals (signal), and signs with no intention as symptom. A well-known character is Roland Barthes, known as the conotative semiotic figure Barthes presents a semiotic theory called the signification of two phases[22]. Barthes explains that this concept begins with the relationship between signifier (expression) and signified (content) in a sign against an external reality that is a signification of the first phase.

It is called Barthes as the dennotation of the most obvious meaning of the mark[23]. The signification of the second stage called the Connotation by Barthes, describes the interactions that occur when the sign meets the feelings or emotions of the reader and the values of its culture. In other words the dennotation is what the mark is depicted on an object, while the meaning of the connotation is how to describe it. The denotative meaning includes the things designated by the words, or the explicit 
relationship between the mark by reference or reality in marking the denotative stage. For example there are human drawings, animals, trees, houses with red, yellow, blue, and white[24]. At the denotative stage only the data information is delivered. While the meaning of the conotatives covers the aspects of color related to the feelings and emotions and cultural values and the viewpoint of a community, example: the image of a smiling face can be interpreted as happiness or expression of humiliation, To understand the meaning of conotative, the other elements must be understood anyway.

In the Liguistic sciences the understanding between the dentations and the connotations is distinguished in its linguistic charge[25]. In the connotations, the aspect of the expression is much greater than the content of understanding found in the dennotation. Thus for the language of the scholarly or information, it is more appropriate to use a denotative understanding. As for the disclosure of expressions of expression, such as novels, poems, essays, or poetry, its use tends to be convolative. Similarly, in visual language for technical drawings, information or aspects related to production, information or aspects related to production, it tends to be used in denotative visual signs, so it is not Meaning refrfitting occurs. As for things that are charged expressions, such as form, image, motif, ornament or things that come into contact with the aspect of humanitis, tends to apply signs of conotative[26]

\section{Method}

He study was conducted in three villages namely Kayeli village, Kubalahin and Wasi, Buru regency. The determination of the research site is conducted purposive[27] with the consideration that the three villages chosen as the research site have a preference of traditional clothes that still have existence in their use. The number of informant that will be interviewed as many as 25 people taken in purposive[28] In consideration of informant is considered as related parties to achieve research objectives[29]. Informan is a community figure, indigenous people, leaders of indigenous institutions and community-relocated research.

The data on this research is derived from primary data sources and secondary data, with data collection techniques used through observation, interviews, questionnaire and library/document studies[30]. In the step of the interview the researcher conducted a thorough interview with the informant[31] and made a direct observation of all activities conducted by the informant. Researchers also sought complementary information related to the traditional clothing use of the roasters in the Namlea market through discussions with the informant[32]. The interview was conducted at 17.00-22.00 where the researchers adjusted the working time and the rest of each informant.

The analytical techniques used in this study are qualitative data analysis following the proposed concept of Miles and Huberman and Spradley[33]. Miles and Huberman, suggests that activities in the analysis of qualitative data are conducted interactively and ongoing continuously at every stage of the research so as to complete and data until saturated. Activity in data analysis is data reduction, data presentation, withdrawal of conclusion.

\section{RESULT}

\subsection{Customary Dress Society Kayeli}

The development of indigenous clothing developed by humans is not merely driven by the fulfillment of biological needs to protect the body, but also driven by cultural needs. In the community of Kayeli, the development of indigenous clothing began with the presence of the tradition of gathering people to listen to admonitions and clues from a leader. For the first time society gathered with conditions of work clothes, for men with naked body or gloves open front while women are incase kebaya. In the next development, there was a change in dress in which the community gatherings also present the guests and invitations from outside the Kayeli community so it is necessary to appreciate their existence.

In the year 1800-1900 Kayeli was the center of Government and the activities of the Community under the rule of Kayeli, where the king often had the Kings, indigenous elders and religious figures to have an influence on the development of traditional clothing Community of Kayeli. For the creation of traditional clothing in the community Kayeli carried out in generations and handed down to some who are held by indigenous elders as people who understand the existence of traditional clothing, customary clothing for the people of Kayeli not are allowed to buy a finished one (buy in store), but traditional clothing is the result of stitching itself and is intended for each person.

The use of traditional clothing in Kayeli village is generally used when certain conditions and times are during traditional ceremonies, rituals, big days, such as weddings, circumcision, and others. This illustrates that the identity of the user is only in the require in certain occasions. The Status of the user of Adat clothing is in the rush to immerse the identity of a tribe scattered in the island of Buru. User Status is also varied. Not only as a protector or just the identity of a region alone, but it has several functions, namely; Adat Clothing has terms of use. The use of customary clothing is one of the code of ethics that has been provisions of the usage by age, social status and administrative structure of the Government.

The beauty of traditional clothing, both shape and color and Hiasan-hiasannya become one of the charms of beauty for both wearer and seer. The color structures and patterns that have been preset in the previous time become the joint's grip on offspring and heirs and it is not easy to change or change according to each person's tastes. Prohibition in the use of customary clothing is arranged when a person performs a hajj that is considered dirty such as throwing big water, killing, stealing and the like. 


\subsection{Customary Dress Society Kubalahin}

Traditional garments of Kubalahin society in general almost the same as the clothes in the villages that are scattered in the district Buru this indicates that the Buru community in general has the same cultural culture as one and the other. As for the difference of traditional clothing between the village and the other village is a mixture of cultures that transmigration to the island Buru, the people of Bugis, Buton and Javanese.

public Kubalahin in a ritual ceremony is obliged to wear traditional clothes that are inherited in the form of hereditary clothing that is kebaya for women. This type of garments was formerly worn by women from among the royal family, teachers, and clergy. In addition, the buttons are also added to the Kebaya hand and the gold pin buttons are accompanied by a Cole or an inner shirt with a sleeve length that is given lace on the top.

This Cole is made of white cloth with buttons on the front and back decoration of embroidery. In addition, the use of white socks and cenela are decorated with gold-coloured flower motifs as footwear and moon-shaped bun on the head reinforced with Konde skewers called Karkupeng. As for men use clothes clothing cele. This garment is patterned with geometric stripes which are generally worn at ceremonies of the King's inauguration, the public washing ceremony, as well as a hot Pela event and combined with the typical Moluccans weaving gloves of similar colored knees. Also added a lenso or handkerchief placed on the shoulders.

The Symbol attached to the indigenous people's clothing Kubalahin is the strata of one that is governed by the composition of clothes such as motifs and red color is a clue for those who are in the middle status and yellow color and pattern for those who are On high social status. Prohibitions and restrictions given regarding activities that could harm or impair kinship such as fighting, Mecuri dormitory kill. With such a limitation is expected custom clothes that are used to be an instrument to create a prosperous community condition.

\subsection{Customary Dress Society Wasi}

In general, the traditional clothing of the people of the community is Kebaya Manampal which is the kebaya of the sleeve to the elbow that is stitched by patch some pieces of cloth arranged and arranged in such a way. The women of the ordinary people in Wasi Village wore the kebaya made of white cotton. This type of Kebaya is usually paired with a palekat cloth that has not been worn to travel by women.

For women, the Wasi community is a few other things that complement this traditional garment. The first is Konde. Actually, the Konde used is a konde similar to Konde in Java in general, there are only a few differences in the accessories supporting Konde. The Konde is made from or resembles gold and silver is called Haspel. This accessory is also paired with Kak ear 4 pieces and shaped like a flower. Not forgetting the Konde comb is placed in the middle of the konde. Lastly, Ron's interest is looped on the Conde and is usually made of cork.

In year 1900 Wasi flourished and became a man-made plateau, Wasi was one of the mountainous regions where it was an important path to reach the lake of shutter. For the creation of customary clothing in the Wasi community is done in hereditary and handed down to some who are held by indigenous elders as people who understand the existence of traditional clothing, customary clothing for the Wasi community is not allowed Bought the finished one. The use of traditional clothing in the village of Wasi is commonly used when certain conditions and times are during traditional ceremonies, rituals, big days, such as weddings, circumcision, and others. This illustrates that the identity of the user is only in the require in certain occasions. The Status of the user's custom clothing identity patterns scattered in the island of Buru. User Status is also varied. Not only as a protector or just the identity of a region alone, but it has several functions, namely; Adat Clothing has terms of use. The use of customary clothing is one of the code of ethics that has been provisions of the usage by age, social status and administrative structure of the Government.

\section{Discussion}

In general, the traditional clothing of the people of the community is Kebaya Manampal which is the kebaya of the sleeve to the elbow that is stitched by patch some pieces of cloth arranged and arranged in such a way. The women of the ordinary people in Wasi Village wore the kebaya made of white cotton[34]. This type of Kebaya is usually paired with a palekat cloth that has not been worn to travel by women.

For women, the Wasi community is a few other things that complement this traditional garment. The first is Konde. Actually, the Konde used is a konde similar to Konde in Java in general, there are only a few differences in the accessories supporting Konde. The Konde is made from or resembles gold and silver is called Haspel[35]. This accessory is also paired with Kak ear 4 pieces and shaped like a flower. Not forgetting the Konde comb is placed in the middle of the konde[36]. Lastly, Ron's interest is looped on the Conde and is usually made of cork.

In year 1900 Wasi flourished and became a man-made plateau, Wasi was one of the mountainous regions where it was an important path to reach the lake of shutter. For the creation of customary clothing in the Wasi community is done in hereditary and handed down to some who are held by indigenous elders as people who understand the existence of traditional clothing, customary clothing for the Wasi community is not allowed Bought the finished one. The use of traditional clothing in the village of Wasi is commonly used when certain conditions and times are during traditional ceremonies, rituals, big days, such as weddings, circumcision, and others. This illustrates that the identity of the user is only in the require in certain occasions. The Status of the user's custom clothing 
identity patterns scattered in the island of Buru[37]. User Status is also varied. Not only as a protector or just the identity of a region alone, but it has several functions, namely; Adat Clothing has terms of use[37]. The use of customary clothing is one of the code of ethics that has been provisions of the usage by age, social status and administrative structure of the Government.

\section{Conclusion}

In practice, customary clothing used by people in Buru District can be seen as customary rules. In addition it serves to protect the body as a cover of the loins and make up the self. However, clothing is created not only as a function of practice, but it also has symbols that are closely related to the position values, the circumstances of the environment, social relations in the kinship system and customary rules and Religion. These outfits and attributes have position values. As well as the use of data clothing in Buru Regency is also commonly used when certain conditions and times are during traditional ceremonies, rituals, big days, such as marriage, circumcision, and others. This illustrates that the identity of the user is only in the require in certain occasions. The Status of the user of Adat clothing in Buru is a pattern of identity of a tribe scattered in the island of Buru.

\section{REFERENCES}

[1] M. C. B. Umanailo, Marginalisasi Buruh Tani Akibat Alih Fungsi Lahan. 2016.

[2] M. C. B. Umanailo, “Desa Sebagai Poros Pembangunan Daerah,” 2015.

[3] M. C. B. Umanailo, "EKSISTENSI WARANGGANA DALAM RITUAL TAYUB."

[4] M. C. B. Umanailo, "Keterbatasan penggunaan teknologi informasi pada pelayanan dan pembelajaran di universitas iqra buru," 2016.

[5] B. Sam et al., "Female Feminism in the Customary Island of Buru," Int. J. Sci. Technol. Res., vol. 8, no. 8, pp. 1877-1880, 2019.

[6] M. C. B. Umanailo, "'recycling' consumerism to construction of modern society," no. 1904, 1964.

[7] M. C. B. Umanailo et al., "Dominance of Economic Capital in Political," in Community Development, Decentralization E Local Autonomy Politic E Democracy, Fisip Universitas Brawijaya, 2018, pp. 1-120.

[8] M. C. B. Umanailo and T. Yatno, Kajian dan Analisis Sosiologi Dalam Bentuk Kumpulan Essay, Makalah dan Opini. 2015.

[9] M. C. B. Umanailo, MASYARAKAT BURU DALAM PERSPEKTIF KONTEMPORER, vol. 53, no. 9. 2015.

[10] B. S. Amanto, M. C. B. Umanailo, R. S. Wulandari, T. Taufik, and S. Susiati, “Local Consumption Diversification,” Int. J. Sci. Technol. Res., vol. 8, no. 8, pp. 1865-1869, 2019.

[11] S. S. F. Assagaf et al., "Construction of the Village as a Development Shaft in the Island Buru," Int. J. Sci. Technol. Res., vol. 8, no. 9, pp. 2139$2143,2019$.

[12] A. Wael et al., “‘ Bupolo' Motion Reading,” Int. J. Sci. Technol. Res., vol. 8, no. 9, pp. 2154-2158, 2019.

[13] S. Yusuf, M. C. B. Umanailo, R. N. Putri, D. Qhuril, M. Ely, and D. Darma, “Village Institution Relations in the Utilization of Village Funds in Namlea District," Int. J. Sci. Technol. Res., vol. 8, no. 8, pp. 1837-1842, 2019.

[14] S. Rachman, H. Hamiru, M. C. B. Umanailo, Y. Yulismayanti, and H. Harziko, "Semiotic Analysis of Indigenous Fashion in The Island of Buru," Int. J. Sci. Technol. Res., vol. 8, no. 8, pp. 1515-1519, 2019.

[15] A. L. Wabula, M. Musyawir, A. Irmawati, B. Rebel, D. M. Darajat, and M. C. B. Umanailo, “Maghrib Movement,” Int. J. Sci. Technol. Res., vol. 8, no. 9, pp. 2134-2138, 2019.

[16] L. J. Buton et al., "The Effect of Nasa Liquid Organic Fertilizer Concentration and Planting Distance to Growth and Production of Beans," Int. J. Sci. Technol. Res., vol. 8, no. 9, pp. 2144-2147, 2019.

[17] M. C. B. Umanailo et al., "Cybercrime Case as Impact Development of Communication Technology That Troubling Society," Int. J. Sci. Technol. Res., vol. 8, no. 9, pp. 1224-1228, 2019.

[18] M. C. B. Umanailo, “Kalesang Dorp in Context De Bouw van Village," 2019, pp. 1-7.

[19] M. C. B. Umanailo, “Overview of Phenomenological Research,” 2019, pp. 1-6.

[20] M. C. B. Umanailo et al., "Comprehension To Village," 2018, pp. 1-2.

[21] M. C. B. Umanailo, I. Hamid, M. Nawawi, S. Pulhehe, S. Yusuf, and A. T. Bon, "Utilization of Qualitative Methods in Research Universities," in Proceedings of the International Conference on Industrial Engineering and Operations Management, 2019, pp. 2076-2081.

[22] M. C. B. Umanailo, R. Umanailo, R. Bugis, and A. T. Bon, "Empowerment Community in Buru Regency," in Proceedings of the International Conference on Industrial Engineering and Operations Management, 2019, pp. 2070-2075.

[23] L. Rumkel, B. Sam, and M. C. B. Umanailo, "Village Head Partnership, Village Consultative Body and Customary Institution in Village Development," Int. J. Sci. Technol. Res., vol. 8, no. 8, pp. 1058-1063, 2019.

[24] M. C. B. Umanailo, N. Handayani, A. Masniati, S. H. Makatita, and S. Lisaholit, "The Urbanization and Diversification of Farmland Namlea Village," Int. J. Sci. Technol. Res., vol. 8, no. 8, pp. 1049-1053, 2019.

[25] A. Hasan Afandi and M. C. B. Umanailo, “Watudakon Citizens 'Social Conflict on Joker Toll Road Development in 2017 in Kesamben District, Jombang Regency," J. Soc. Sci. Res., vol. Special Is, no. 5, pp. 656-661, 2018.

[26] M. C. B. Umanailo, Sosiologi Hukum, 1st ed. Namlea: FAM PUBLISHING, 2016.

[27] M. C. B. Umanailo, "Teknik praktis grounded theory dalam penelitian kualitatif," 2018, no. April, p. 127.

[28] M. C. B. Umanailo, ILMU SOSIAL BUDAYA DASAR, 1st ed. Namlea: FAM PUBLISHING, 2015.

[29] R. I. Umasugi, C. C. Costa, M. Apriyanto, M. C. B. Umanailo, and N. Mufidah, "Dominance of Economic Capital in the Political," Int. J. Sci. 
Technol. Res., vol. 8, no. 9, 2019.

[30] M. C. B. Umanailo, “Integration of Community Empowerment Models [Pengintegrasian Model Pemberdayaan Masyarakat]," Proceeding Community Dev., vol. 2, p. 268, Mar. 2019.

[31] M. C. B. Umanailo, “Overview Phenomenological Research," pp. 1-6.

[32] N. Nuraini et al., "Political Policy for the development of Education," Int. J. Sci. Technol. Res., vol. 8, no. 10, 2019.

[33] M. C. B. Umanailo, MASYARAKAT BURU DALAM PERSPEKTIF KONTEMPORER (Kajian Kritis Perubahan Sosial di Kabupaten Buru), vol. 1. Namlea, 2017.

[34] R. Bugis et al., “Workers in the Namlea Market," Int. J. Sci. Technol. Res., vol. 8, no. 9, pp. 2044-2047, 2019.

[35] H. Hamiru et al., "Eucalyptus Oil Workers," Int. J. Sci. Technol. Res., vol. 8, no. 9, pp. 1817-1820, 2019.

[36] M. C. B. Umanailo, M. Yulisvestra, K. K. Oki, W. Mulyasari, and R. Ridwan, "The Thought of Emile Durkheim in the Contestation of Development in Indonesia," Int. J. Sci. Technol. Res., vol. 8, no. 8, pp. 1881-1885, 2019.

[37] W. Malmia et al., “Problem-Based Learning as an Effort to Improve Student Learning Outcomes," Int. J. Sci. Technol. Res., vol. 8, no. 9, pp. 11401143, 2019. 